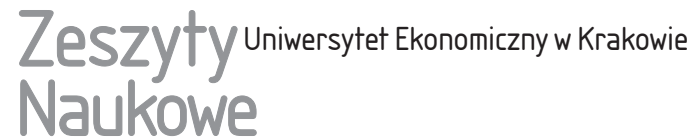

\section{Crowdfunding jako innowacyjna metoda finansowania start-upów}

\section{Streszczenie}

Crowdfunding jest innowacyjną metodą finansowania, która polega na pozyskiwaniu środków finansowych za pośrednictwem internetu w celu realizacji projektów zarówno o charakterze filantropijnym, jak i komercyjnym. Dotychczas odgrywał on niewielką rolę w porównaniu z innymi, innowacyjnymi formami finansowania, z pominięciem tradycyjnych pośredników. Wynika to z jego względnie krótkiej historii funkcjonowania, słabej znajomości jego zalet i ograniczeń oraz braku w wielu krajach odpowiednich uregulowań prawnych i przekonania o jego skuteczności. Odnosi się to szczególnie do krajów Europy Środkowo-Wschodniej, w tym Polski. Kraje te ze względu na pozostawanie przez długi czas w izolacji od światowej gospodarki rynkowej tylko stopniowo i z opóźnieniem adaptują jej instrumenty, w tym innowacyjne metody finansowania. Wynika z tego potrzeba upowszechnienia wiedzy na ten temat i wykazania, że crowdfunding może mieć istotne znaczenie dla rozwoju szczególnie młodych firm - start-upów, jako komplementarne, a niekiedy także substytucyjne źródło ich finansowania. Tezę tę autor artykułu udowadnia, posługując się empirycznymi, teoretycznymi i ogólnologicznymi metodami badawczymi, wykorzystując dostępna literaturę przedmiotu, raporty organizacji międzynarodowych i internet.

Słowa kluczowe: crowdfunding, internet, start-up, innowacja finansowa.

Klasyfikacja JEL: D25.

Jan Rymarczyk, Wyższa Szkoła Bankowa w Poznaniu, Wydział Finansów i Bankowości, ul. Powstańców Wielkopolskich 5, 61-895 Poznań, e-mail: jan.rymarczyk@ue.wroc.pl, ORCID: https://orcid.org/0000-0003-4701-439X. 


\section{Wprowadzenie}

Crowdfunding określany jest $\mathrm{w}$ języku polskim jako finansowanie społecznościowe, jednak jak w wielu innych przypadkach w ekonomii, a szczególnie w finansach, powszechnie używany jest termin angielski. Ten innowacyjny sposób finansowania różnych projektów, charytatywnych, kulturowo-artystycznych, społecznych i gospodarczych, należy niewątpliwie do najmłodszych, ponieważ jego współczesne zastosowanie przypada na koniec XX w. i początek XXI w. i związane było z branżą artystyczną. Jego rozwój stał się możliwy dzięki upowszechnieniu się nowoczesnych technologii informacyjno-komunikacyjnych, w tym przede wszystkim internetu. Ten przełomowy wynalazek spowodował rewolucyjne zmiany praktycznie we wszystkich sferach funkcjonowania społeczeństw, w tym przede wszystkim w gospodarce i finansach. Wytwarzanie produktów i usług oparte zostało na modelu rozproszonych sieci, w ramach których następuje udostępnianie i podział zasobów oraz działań pomiędzy różne kooperujące ze sobą podmioty (sharing economy). Coraz większą popularność w obrębie tego modelu zyskują ich interakcje finansowe bez udziału tradycyjnych pośredników, takich jak banki i inne instytucje finansowe, czyli tzw. finansowanie oparte na współpracy (collaborative finance) (Mitręga-Niestrój 2013, s. 87; Koch 2012, s. 32-33; Hamari, Sjöklint i Ukkonen 2016, s. 260-271).

Pojęcie crowdfundingu wywodzi się z szerszego i wcześniej datowanego procesu mobilizacji uczestnictwa wielu niezidentyfikowanych podmiotów w realizacji różnych elementów określonego przedsięwzięcia za pośrednictwem portali społecznościowych (Kalabota 2014, s. 4; https://pl.wikipedia.org/wiki/Crowdsourcing, data dostępu: 6.01.2018). W szczególności jego rozwój, a później też rozwój crowdfundingu związany jest z przemianami, jakie nastąpiły w technologii online. Chodzi tu o przejście od sieci Web 1.0 do Web 2.0, które oznaczało zwiększenie interaktywności i współpracy użytkowników oraz ich uczestnictwa w tworzeniu zawartości sieci Web.

Celem artykułu jest charakterystyka tego nowoczesnego i alternatywnego sposobu finansowania, ocena jego przydatności do realizacji projektów z różnych sfer działalności i prezentacja krótkiej historii jego rozwoju. Autor stara się wykazać, że crowdfunding może być traktowany jako komplementarny lub substytucyjny sposób finansowania o względnie jeszcze niewielkim, aczkolwiek rosnącym znaczeniu, szczególnie dla małych firm i start-upów. Artykuł oparty został na opracowaniach zwartych, periodycznych, raportach oraz źródłach internetowych. Wykorzystane zostały takie metody badawcze, jak: obserwacja pośrednia, opis, pomiar, klasyfikacja, weryfikacja, analiza przyczynowo-skutkowa, synteza $\mathrm{i}$ indukcja. 


\section{Pojęcie i modele crowdfundingu}

Crowdfunding jest to sposób gromadzenia zasobów finansowych zwykle za pośrednictwem platformy internetowej od potencjalnie dużej liczby osób i instytucji, by zrealizować określony cel, w formie bezzwrotnej dotacji, za określonym, na ogół symbolicznym wynagrodzeniem, pożyczki lub udziału w kapitale jego inicjatora. $\mathrm{Z}$ tej definicji wynikają następujące jego modele (Wilson i Testoni 2014, s. 2-3; https://mfiles.pl/index.php/Crowdfunding, data dostępu: 27.03.2018; New Approaches... 2015, s. 54-56; Crowdfunding for SMEs 2016, s. 10-13):

- model donacyjny (donation-based model) - polega na wpłatach ofiarodawców na określony cel charytatywny lub dla organizacji non-profit bez oczekiwania rekompensaty. Jest to najbardziej rozpowszechniona forma crowdfundingu, bazująca na niematerialnym zainteresowaniu inwestorów danym projektem lub działalnością. Niekiedy ten kanał wykorzystywany jest także przez organizacje profit dla celów, które mogą znaleźć uznanie określonej grupy społeczeństwa;

- model nagrodowy, inaczej sponsorski (reword-based model, sponsorship model) - oparty na niefinansowej gratyfikacji dla wpłacających. Nagrody mogą mieć charakter symboliczny, jak np.: długopisy, kubki, portmonetki, T-shirty z określonym nadrukiem, lub mogą to być wczesne wersje produktu lub produkty po obniżonej cenie. Przyrzeczenie otrzymania wczesnej wersji produktu po obniżonej cenie $\mathrm{w}$ zamian za dokonaną wpłatę niekiedy traktowane jest jako odrębny model crowdfundingu, tzw. model przedzakupowy lub przedsprzedażowy (pre-purchase model, pre-selling model) (Crowdfunding for SMEs 2016, s. 11);

- model pożyczkowy (lending-based model, peer-to-peer lending - P2P) - oznacza udzielanie zwykle niezabezpieczonych, prywatnych pożyczek bez pośrednictwa tradycyjnych instytucji finansowych w celu realizacji określonego przedsięwzięcia. Udzielający pożyczek otrzymują oprocentowanie ratalne i zwrot kwoty głównej na koniec okresu. Może też być stosowane rozwiązanie polegające na zwrocie kwoty głównej z ustalonym udziałem w zyskach, w przypadku powodzenia projektu, bez oprocentowania. Instytucją obsługującą te transakcje, tak jak w przypadku innych form crowdfundingu, jest specjalna platforma elektroniczna;

- model inwestycyjny, kapitałowy (equity-based model, crowdinvesting) w tym przypadku fundatorzy otrzymują przyrzeczenie udziału w zyskach, jeśli dane przedsięwzięcie przyniesie dochód lub określoną z góry liczbę akcji firmy, inicjatora projektu, zależne od wysokości wpłaconej kwoty (rys. 1).

Dla poszukującego środków finansowych, czyli inicjatora, kluczową kwestią jest ocena prawdopodobnego zwrotu z planowanego projektu, ponieważ od tego zależą rozmiary rekompensaty dla inwestorów i wartość oferowanych akcji. W tym modelu crowdfundingu ponoszą oni największe ryzyko ze względu na niepewność co do przyszłych zdarzeń biznesowych. Ponieważ jednak pojedyncze wpłaty 


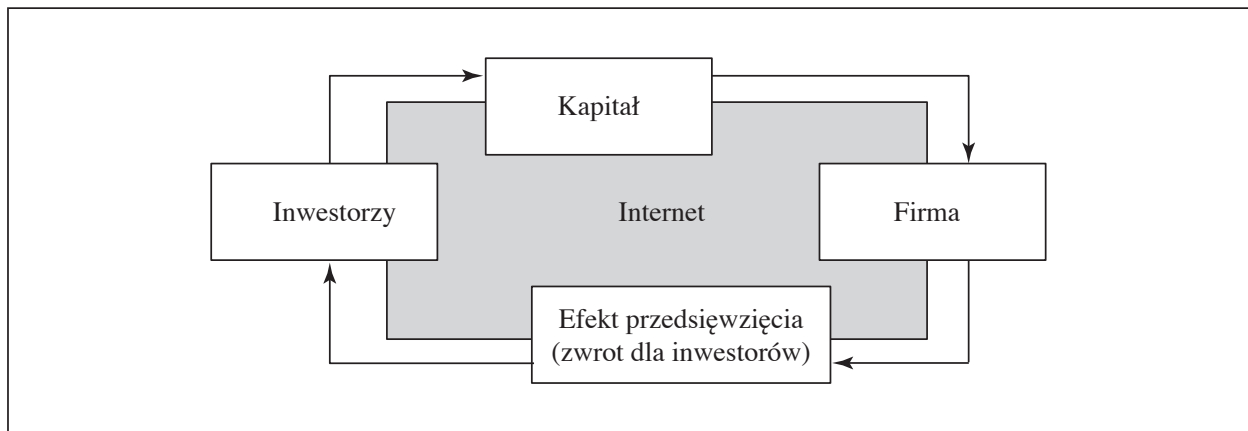

Rys. 1. Mechanizm funkcjonowania crowdfundingu inwestycyjnego Źródło: opracowanie własne na podstawie (Beck 2014, s. 9).

dotyczą na ogół niewielkich kwot, to w przypadku nieosiągnięcia zakładanego przez inicjatora efektu straty poszczególnych inwestorów będą na ogół niewielkie. Ponadto dla niektórych z nich głównym motywem może być nie osiągnięcie zysku, ale wsparcie określonego przedsięwzięcia lub satysfakcja z uczestnictwa w nim.

\section{Podmioty crowdfundingu}

Każdy z modeli crowdfundingu integruje trzy podmioty, tj. fundatorów (inwestorów), przedsiębiorcę (inicjatora) i platformę. Rodzaj modelu decyduje o ich cechach i występujących pomiędzy nimi różnicach. Przeprowadzone badania wskazują, że na ogół fundatorzy stanowią elitę użytkowników sieci, zwykle należą do klasy średniej, są dobrze wykształceni i w średnim wieku, żonaci i mają dostęp do szybkiego internetu (Schwienbacher i Larralde 2010, s. 8). Na tej podstawie wyprowadzona jest teza, że społeczności mogą być bardziej inteligentne od jednostek i dokonywać bardziej racjonalnych wyborów projektów inwestycyjnych, co przemawiałoby za crowdfundingiem w relacji do innych modeli inwestowania, takich jak $\mathrm{np}$. anioły biznesu (business angels). Teza ta jednak nigdy nie została zweryfikowana. Przeciwnie, wydaje się, że w przypadku modelu donacyjnego i nagrodowego inwestorzy kierują się emocjami, a nie analizami efektywności danego projektu i związanego z nim ryzyka.

Biorąc pod uwagę kryterium motywów i sposobu postępowania fundatorów w poszczególnych modelach crowdfundingu, można wyróżnić następujące kategorie inwestorów:

- filantropi, związani z modelem donacyjnym, kierujący się motywami humanitarnymi,

- hobbyści, występujący w modelu nagrodowym, czerpiący satysfakcję z uczestnictwa w określonym przedsięwzięciu, 
- kredytodawcy w modelu pożyczkowym, uzyskujący korzyści z tytułu oprocentowania prywatnych pożyczek.

Jeśli chodzi o inwestorów w modelu kapitałowym, to według Instytutu EFNW Uniwersytetu w Oldenburgu istnieją takie ich grupy, jak (Post 2017, s. 4):

- inwestujący dla przyjemności - są to osoby posiadające doświadczenie zdobyte w crowdfundingu nagrodowym, które zwykle przeznaczają na ten cel od 25 do 100 euro;

- wspierający produkt - czyli zainteresowani otrzymaniem w zamian za wsparcie pierwszej wersji produktu, przy czym korzyści materialne odgrywają dla nich drugorzędną rolę, liczy się raczej prestiż;

- inwestorzy z kręgu przyjaciół i rodziny - podstawowe znaczenie mają tu więzi personalne. Prowadzą oni aktywną kampanię, wspierając przedsięwzięcie. $\mathrm{W}$ porównaniu z innymi inwestorami oferują oni ponadprzeciętne kwoty i nie oczekują wysokich zwrotów;

- inwestujący dla zysku - oczekują zysków wyższych niż przeciętne. Dywersyfikują oni ryzyko, inwestując w różne projekty kapitałowego crowdfundingu jednorazowo ok. 250 euro;

- anioły crowdfundingu - również oczekują ponadprzeciętnych zysków, inwestując jednak kwoty wynoszące przeciętnie ok. 5 tys. euro.

Uczestników crowdfundingu finansowego cechuje na ogół większy tzw. apetyt na ryzyko aniżeli kapitalistów venture lub anioły biznesu.

Inicjatorzy, stanowiący drugą kategorię podmiotów crowdfundingu, mogą reprezentować różne branże ze sfery kultury, nauki, medycyny, działań społecznych i biznesowych. Mogą oni poszukiwać środków na produkcję muzyczną, filmową, organizację imprez rozrywkowych, badania naukowe, tworzenie oprogramowania komputerowego, serwisów internetowych, wsparcie rozwoju szpitali, zakup sprzętu medycznego, budowę obiektów użyteczności publicznej czy organizację kampanii wyborczych. Natomiast działania biznesowe mogą dotyczyć różnych projektów z zakresu przemysłu, handlu, usług, nieruchomości, ochrony środowiska, rozwoju nowych technologii itd. Na ogół jednak crowdfunding jest dogodną opcją dla niższego poziomu finansowania, tj. projektów małych lub średniej wielkości. Istniejąca luka w finansowaniu małych i średnich przedsiębiorstw (MŚP) może być w pewnym stopniu zniwelowana z pomocą crowdfundingu, szczególnie pożyczkowego i inwestycyjnego. Mogą one bowiem uzyskiwać pożyczki poza systemem bankowym, nie posiadając odpowiedniego zabezpieczenia i historii finansowej firmy, oraz mogą oferować niekiedy niższe stopy procentowe, wykorzystując do pewnego stopnia niematerialne motywacje pożyczkodawców. W szczególności inwestycyjny crowdfunding może być atrakcyjny dla start-upów, które potrzebują względnie niewielkich kwot, uzupełniających własne środki przeznaczone na rozpoczęcie działalności gospodarczej i zastępu- 
jących nieosiągalny kredyt bankowy lub finansowanie z innych źródeł, takich jak venture capital, anioły biznesu lub publiczne programy (środki Unii Europejskiej lub rządowe). W niektórych przypadkach innowacyjne start-upy za pośrednictwem platform były finansowane nawet przez duże firmy, oferujące jednocześnie względnie duże kwoty. Duży stopień skomplikowania projektów, opartych na nowoczesnych, innowacyjnych technologiach może jednak stanowić przeszkodę w zebraniu środków od „tłumu” (crowd) ze względu na brak odpowiedniej wiedzy tworzących go osób. W takich przypadkach firmy powinny korzystać z platform wyspecjalizowanych w pozyskiwaniu specjalnych grup inwestorów, dysponujących odpowiednimi kwalifikacjami i poszukujących takich okazji inwestycyjnych. Mogą oni oprócz środków finansowych wnieść także swoją wiedzę, doświadczenie i sieciowe powiązania biznesowe. Crowdfunding nie jest opcją zalecaną dla firm, które dysponują unikalną wiedzą, która może być skopiowana przez konkurentów, jeśli nie jest możliwe lub prawnie bardzo trudne ukrycie jej przed potencjalnymi imitatorami (New Approaches... 2015, s. 57). Może on być także nieodpowiedni dla firm wymagających znacznych nakładów finansowych we wczesnych stadiach rozwoju lub wsparcia poinwestycyjnego, których mogą dostarczyć tylko inwestorzy instytucjonalni.

Profesjonalne platformy internetowe stanowią zasadniczy instrument realizacji crowdfundingu, pośrednicząc $w$ relacjach pomiędzy fundatorami a gromadzącymi środki finansowe na różne cele. Zakres ich funkcji w tym względzie jest różny i zależy od modelu crowdfundingu, stopnia specjalizacji platformy, doświadczenia i kwalifikacji twórców platformy, stosowanych technik gromadzenia pieniędzy oraz specyfiki branży, w której funkcjonuje firma inicjator, i przepisów prawa regulujących ich funkcjonowanie w danym kraju (Dziuba 2015, s. 185-186: Kalinowski 2015, s. 41). Należy zaznaczyć, że operator platformy nie jest stroną umowy pomiędzy inwestorem a inicjatorem projektu, natomiast jest podmiotem odrębnych, prawnych zobowiązań z nimi. Jego główne zadanie polega na prezentowaniu na swojej witrynie informacji o projekcie, pozyskiwaniu inwestorów, gromadzeniu środków finansowych od nich w celu przekazania ich inicjatorowi lub zwrotu fundatorom w przypadku, gdy realizowany jest model ,wszystko albo nic" (all or nothing), tzn. gdy nie została zebrana ustalona z góry kwota pieniędzy. Ponadto platforma może jako reprezentant inwestorów sporządzać due diligence projektu i monitorować jego realizację. Może ona także na zlecenie inicjatora przeprowadzać selekcję inwestorów, ustalając poziom minimalnej wpłaty. Przykładem takich platform są Circlellp i Funders Club w USA oraz Seedups w Irlandii (Wilson i Testoni 2014, s. 9-10). Inne kryterium selekcji to test na znajomość ryzyka związanego z finansowaniem danego projektu przez wybranych inwestorów, co stosują np. platformy Seedrs i Crowdcube w USA. Z kolei platforma MyMicroinvest w Belgii zwykle oferuje inwestorom możliwość wspólnego inwestowania 
w dany projekt z aniołami biznesu. Niektóre platformy realizują tylko jeden model crowdfundingu, inne zaś łączą kilka modeli, jak np. rumuńska platforma Multifinanture. Dość często spotykana jest specjalizacja branżowa platform, czyli koncentracja ich działalności np. na projektach ekologicznych, związanych z nieruchomościami, z innowacyjnymi technologiami lub start-upami z różnych branż. Platformy różnią się także ze względu na zasięg geograficzny, mogą mieć charakter lokalny, krajowy, lub nawet międzynarodowy. Stosują one także różne strategie dotyczące gromadzenia środków finansowych, takie jak model „wszystko albo nic", o którym już była mowa, model „wszystko i więcej” (all and more), co oznacza możliwość przekroczenia ustalonej kwoty do pozyskania, oraz model „wszystko” (keep it all), czyli przekazania inicjatorowi zebranej kwoty, niezależnie od jej wysokości.

Operatorzy platform za swoją działalność pobierają wynagrodzenie zwykle w wysokości 5-10\% zebranej kwoty, a także czasami wstępną, uzgodnioną z inicjatorem opłatę pobieraną z góry. Niektórzy jednak obciążają również inwestorów albo stałą opłatą, albo zależną od osiąganego przez nich zysku, w przypadku inwestycyjnego crowdfundingu. Na ogół platformy deklarują stosowanie dobrych praktyk biznesowych, notowane są jednak przypadki odstępstwa od nich spowodowane brakiem długookresowej wizji oferowanego projektu, niekompetencją, oportunizmem lub nieuczciwością, co powoduje utratę pieniędzy inwestorów i dobrego imienia platformy.

Liczba platform crowdfundingu na świecie stale rośnie, w 2012 r. szacowana była na ok. 600 aktywnych, a w 2018 r. było ich już ponad 2000. W Polsce do zaangażowanych w różne formy crowdfundingu i mających największe znaczenie należały: Bestfund.com, PolakPotrafi.pl, Crowdfunders.pl, Megatotal.pl, Crowdfunding platform, Wspieram.to, Siepomaga.pl, Wspieramkulture.pl i Zrzutka.pl.

\section{Przebieg procesu crowdfundingu}

Przebieg crowdfundingu można podzielić na cztery fazy (Wilson i Testoni 2014, s. 4, https://www.grin.com/document/372313, data dostępu: 27.03.2018), tj.:

1) fazę selekcji i oceny projektu,

2) fazę inwestowania,

3) fazę poinwestycyjną,

4) fazę wyjścia z inwestycji (w przypadku kapitałowego crowdfundingu).

Proces crowdfundingu rozpoczyna się od przedstawienia projektu, na który firma chce pozyskać finansowanie, wybranej platformie internetowej, specjalizującej się w zbieraniu funduszy na określonego rodzaju przedsięwzięcia. Platforma dokonuje oceny zgłoszonego projektu i firmy reprezentującej go, z uwzględnie- 
niem różnych kryteriów. Inne kryteria dotyczą projektów charytatywnych, a inne - kapitałowych, których celem jest osiągnięcie zysku.

W przypadku projektów kapitałowych platforma bada dokładnie m.in. biznesplan projektu, sytuację finansową firmy i jej strategię. Na tej podstawie dokonuje ona selekcji projektów, które jej zdaniem rokują największe nadzieje na odpowiednie zainteresowanie ze strony inwestorów i odpowiadają profilowi jej działalności. Po podjęciu decyzji o udostępnieniu przez platformę wybranym firmom swojej strony następuje podpisanie umowy z nimi i przekazanie on-line wszystkich ważnych informacji o projektach i firmach potencjalnym fundatorom (inwestorom). W tej fazie niezwykle ważny jest odpowiedni marketing projektów i komunikacja $\mathrm{z}$ inwestorami w celu przekonania ich o sensie uczestnictwa w oferowanych projektach. Na podstawie uzyskanych informacji i swojej wiedzy oraz kwalifikacji dokonują oni oceny projektów i firm i podejmują decyzje o uczestnictwie w nich. Na tym etapie, tj. inwestowania, ustalana jest też pomiędzy operatorem platformy a managementem firmy minimalna i maksymalna kwota wymagana do zebrania oraz czas trwania zbierania funduszy, który przeciętnie wynosi do 60 dni. Po jej uzyskaniu od inwestorów następuje przekazanie jej firmom. Niespełnienie kryterium jej wysokości, o czym już była mowa, powoduje jej zwrot fundatorom. W fazie poinwestycyjnej platforma monitoruje realizację projektów i ewentualnie spełnia także funkcje doradcze dla firmy. Również inwestorzy monitorują projekty, szczególnie gdy ich wynagrodzenie zależne jest od ich sukcesów. Te działania platformy i inwestorów ułatwia okresowe, najczęściej kwartalne i roczne raportowanie efektów realizacji projektów przez firmy. W fazie zakończenia inwestycji, jeśli przyniosą one zyski, inwestorzy partycypują w nich w z góry określony sposób i ewentualnie sprzedają akcje lub udziały w firmach.

Kapitałowe uczestnictwo, czyli crowdinvesting, najczęściej przyjmuje formę finansowania mezzanine, czyli finansowego instrumentu mającego cechy kapitału obcego i kapitału własnego. Kapitał mezzanine ma charakter podrzędny w stosunku do kapitału obcego i nadrzędny w stosunku do kapitału własnego. Oznacza to, że w przypadku upadłości firmy w pierwszej kolejności będą zaspokojone roszczenia wszystkich dostawców obcego kapitału (kredyty bankowe i kupieckie), a dopiero później własnego kapitału (Schwethelm 2014, s. 26; Crowdfunding in Europe... 2016, s. 75-76). Czas trwania projektów inwestycyjnych może być nieograniczony, ale wtedy umowa powinna zawierać klauzulę możliwości wyjścia z inwestycji na żądanie jednej ze stron. Inna opcja to z góry określony czas realizacji projektu, który zwykle w praktyce przeciętnie wynosi do ośmiu lat. 


\section{Zalety i wady crowdfundingu}

Tak jak inne formy finansowania, crowdfunding ma pozytywne i negatywne strony (Onnée i Renault 2016, s. 316-318). Te pierwsze wydają się przeważać, a tych drugich w dużej mierze można uniknąć poprzez racjonalne postępowanie.

Crowdfunding nieodłącznie związany jest $\mathrm{z}$ internetem, który jest najbardziej efektywnym medium komunikacyjnym wszech czasów. Oznacza to przeniesienie jego pozytywnych cech na użytkownika. Dzięki internetowi inicjator crowdfundingu może za pośrednictwem platformy w czasie rzeczywistym dotrzeć z multimedialną ofertą do nieograniczonej liczby potencjalnych fundatorów i nawiązać z nimi komunikację zwrotną, urealniającą i zwiększającą kompleksowość informacji w inicjowanym projekcie, postępach w jego realizacji i efektach finansowych po jego rozpoczęciu. Jest to również szybki sposób zgromadzenia funduszy, i na ogół bez ponoszenia wstępnych opłat, co ma szczególne znaczenie w wypadku projektów charytatywnych.

Jeśli chodzi o crowdfunding inwestycyjny, jego zalety polegają na tym, że (Schwethelm 2014, s. 31-33; https://www.nibusinessinfo.co.uk.content/advantages-and-disvantages-crowdfunding, data dostępu: 27.03.2018):

- pozyskane środki finansowe w formie mezzanine mogą być z ekonomicznego i bilansowego punktu widzenia traktowane jako kapitał własny. Zwiększenie jego udziału oznacza większą gwarancję spłaty zobowiązań, wyższy rating i większe możliwości korzystania z innych źródeł finansowania (kredytu bankowego, leasingu itp.);

- nie jest wymagane posiadanie przez firmę zabezpieczenia, jak to ma miejsce w przypadku kredytu bankowego;

- nie następuje rozwodnienie kapitału i zagrożenie utraty kontroli nad firmą;

- inwestorzy nie mają prawa współdecydowania i kontroli nad firmą;

- ma miejsce obniżenie ryzyka inwestycyjnego dla firmy, ponieważ jego część przejmują inwestorzy;

- udział niektórych inwestorów może wiązać się ze wsparciem firmy w zarządzaniu projektem;

- warunki umowy z inwestorami mogą być elastycznie kształtowane w zakresie czasu trwania, finansowania, warunków wynagrodzenia i zwrotu zainwestowanych kwot;

- firma osiąga pozytywne efekty marketingowe. Staje się ona znana szerokiemu gronu potencjalnych inwestorów. Sukces projektu może przyczynić się do zwiększenia popytu na produkty firmy, jej obrotów i zysków, a także może ułatwić pozyskanie środków w następne projekty crowdfundingu inwestycyjnego;

- inwestorzy mogą stać się lojalnymi klientami firmy i promować jej wyroby; 
- sukces w gromadzeniu środków jest dobrym testem na to, czy idea lub projekt znajdą uznanie publiczne.

Ujemne strony crowdfundingu związane są z:

- nakładami organizacyjnymi i finansowymi, które należy ponieść, aby przygotować projekt;

- faktem, że wiele projektów nie jest akceptowanych przez platformy, co oznacza straty nakładów;

- wymaganiem przez niektóre platformy wstępnych opłat, niezależnych od powodzenia crowdfundingu;

- faktem, że jeśli nie zostaje zebrana wymagana dla realizacji projektu kwota, to fundusze zwracane są inwestorom, a firma ponosi straty związane z kosztami przygotowania projektu i ewentualnie ze wstępnymi opłatami;

- dość znacznymi kosztami pozyskania funduszy, ponieważ platformy zwykle pobierają zależną od efektów projektu prowizję. Mogą także pobierać opłaty za dodatkowe świadczenia. Jeśli wymagane jest sporządzenie prospektu w celu pozyskania kapitału, to koszty znacznie wzrastają;

- szeroko zakrojonymi obowiązkami informacyjnymi firmy i utrzymywaniem komunikacji z inwestorami;

- ograniczonymi możliwościami indywidualnego kształtowania ofert przez firmy ze względu na tendencję do standaryzowania portali przez platformy w celu ograniczenia kosztów;

- trudnym do przewidzenia ryzykiem realizacji projektu lub idei, które może spowodować ich fiasko i w konsekwencji utratę funduszy inwestorów i reputacji firmy (negatywny marketing);

- ograniczeniem czasu do 60 dni;

- tym, że jeśli produkt lub idea nie zostaną zabezpieczone patentem lub prawem autorskim, to mogą zostać skopiowane przez konkurentów;

- zbyt optymistyczną oceną możliwych do osiągnięcia dochodów i zbyt wysokimi wynagrodzeniem dla inwestorów oferowanym w celu ich przyciągnięcia, co może spowodować, że projekt będzie dla firm nieopłacalny;

- ograniczeniami prawnymi, zwłaszcza crowdfundingu opartego na emisji papierów wartościowych w niektórych krajach;

- faktem, że rynek crowdfundingu jest młody i podlega znacznym zmianom, co stwarza niebezpieczeństwo pojawienia się platform, których operatorzy ze względu na brak doświadczenia, nieznajomość przepisów prawa lub ich nieprzestrzeganie oraz wskutek nieuczciwości mogą narazić inwestorów i firmy na znaczne straty materialne i moralne.

Wymienione tu zalety i wady crowdfundingu mają częściowo realny, a częściowo potencjalny charakter. Ich wystąpienie zależne jest zarówno od czynników obiektywnych - zasad funkcjonowania danej formy biznesu lub działalności 
non profit determinowanych przepisami prawa i zwyczajami, jak i subiektywnych wynikających z siły negocjacyjnej stron transakcji, ich kwalifikacji, doświadczenia, uczciwości i szczęścia.

\section{Rozwój crowdfundingu}

Współczesny crowdfunding, tak jak w zasadzie wszystkie nowoczesne, innowacyjne formy finansowania, zapoczątkowany został w Stanach Zjednoczonych. Symbolicznie za pierwszy jego przypadek, słusznie lub nie, uważa się zebranie w internecie w 1997 r. przez amerykańskich fanów brytyjskiej grupy rockowej Marillion 60 tys. USD na sfinansowanie kosztów jej koncertów w USA (Crowdfunding for SMEs 2016, s. 6; https://pl.wikipedia.org/wiki/Crowdfunding, data dostępu: 27.03.2018). Na początku XXI w. powstało kilka platform związanych z finansowaniem branży muzycznej, co pozwala uważać tę branżę jako prekursora współczesnego crowdfundingu. Natomiast wielobranżowe portale crowdfundingowe pojawiły się pod koniec pierwszego dziesięciolecia obecnego wieku, w tym tak znane jak Indiegogo Crowdfunder, Experiment, Chuffed, Gofundme (https:// www.digitaltrends, data dostępu: 4.07.2019) i obecnie największa na świecie Kickstarter. Nieco później zaczęły powstawać portale społecznościowe w Europie Zachodniej, stopniowo także w Środkowo-Wschodniej. W Polsce pierwszy portal - PolakPotrafi.pl utworzony został w 2011 r. Obecnie crowdfunding ma charakter globalny, tzn. występuje na wszystkich kontynentach z wyjątkiem Antarktydy. Największy udział w nim ma Ameryka Północna, następnie Europa, a najmniejszy - pozostałe kontynenty (dla 2014 r. wynosił on odpowiednio: ponad 60\%, ok. 36\% i ok. 4\%) (Wilson i Testoni 2014, s. 3). Dynamiczny wzrost crowdfundingu rozpoczął się w 2009 r., kiedy to wyniósł on globalnie 530 mln USD i osiągnął szacowany w 2013 r. poziom 5100 mln USD, czyli wzrósł on prawie 10-krotnie (rys. 2).

Największe znaczenie miały modele donacyjny i pożyczkowy (rys. 3). W 2010 r. ponad połowa zebranych funduszy przeznaczona była na cele charytatywne. W 2012 r. ich udział w globalnym wolumenie zmniejszył się do 37\%, natomiast wzrósł do $44 \%$ udział modelu pożyczkowego.

Dwa pozostałe modele odgrywały znacznie mniejszą rolę. Podczas gdy udział modelu nagrodowego wzrósł w branym pod uwagę okresie do $14 \%$, to crowdfunding inwestycyjny spadł do 4\%. Najwiekszym rynkiem finansowania społecznościowego była Europa, natomiast w USA ze względu na bariery prawne nie wykazywało ono rozwoju. Dopiero w 2012 r. podjęto tam pierwszą próbę prawnego uregulowania crowdfundingu (ustawa Jump-start Our Business Startups - JOBS). W większości krajów w ogóle nie istnieją regulacje prawne bezpośrednio odnoszące się do crowdfundingu. W Europie pewne działania prawne podjęte zostały 


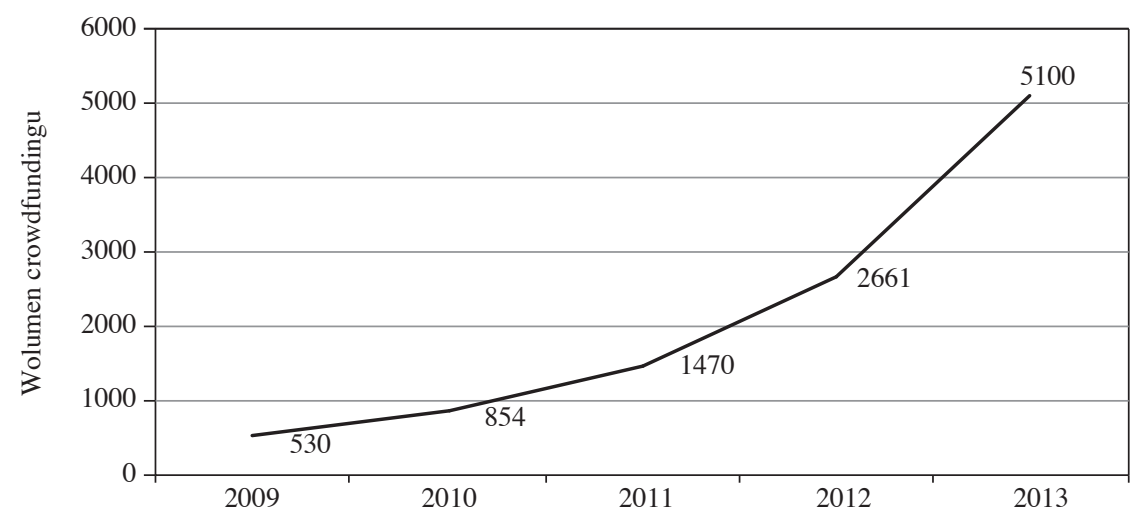

Rys. 2. Zmiany wolumenu crowdfundingu w latach 2009-2013 (w mln USD) Źródło: (Wilson i Testoni 2014, s. 3).

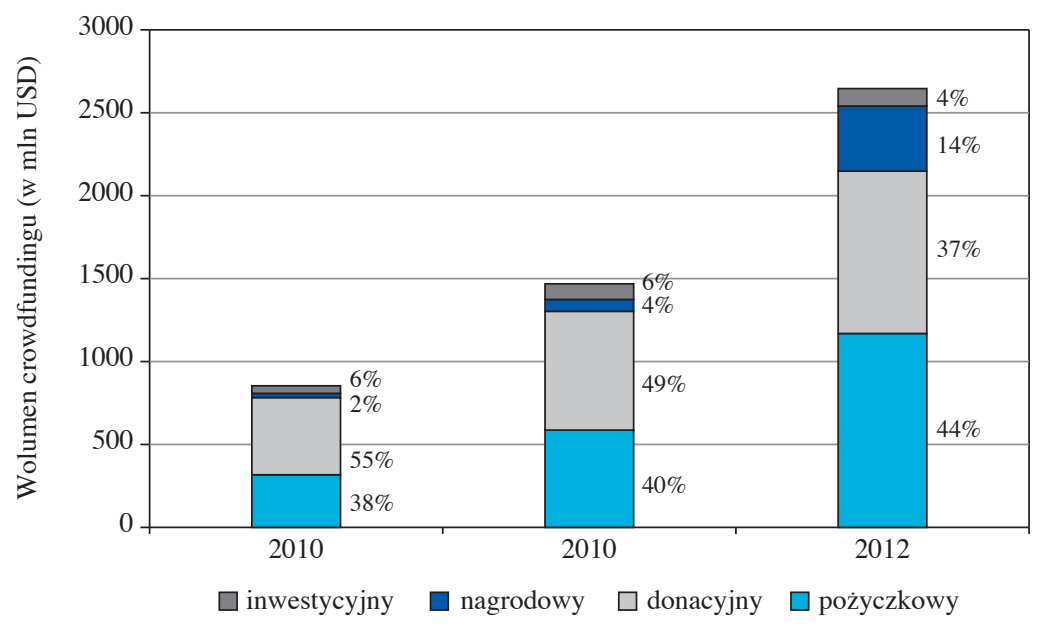

Rys. 3. Zmiany udziału poszczególnych form crowdfundingu w latach 2010-2012 (w \%) Źródło: (Wilson i Testoni 2014, s. 3).

np. we Włoszech, Wielkiej Brytanii, Hiszpanii, Francji i w Niemczech, a o charakterze konsultacyjnym - na szczeblu Komisji Europejskiej.

W Polsce, tak jak w wielu innych krajach (Niam i Shamika 2017, s. 22-23), brak regulacji prawnych crowdfundingu, tym niemniej jest on realizowany na podstawie różnych uregulowań prawnych odnoszących się do darowizn, przed- 
sprzedaży, pożyczek, sprzedaży udziałów w spółkach z o.o., emisji akcji itd. Brak bezpośrednich regulacji prawnych hamuje jego rozwój. W 2018 r. wartość wpłat za pośrednictwem największych platform szacowana była na ponad $67 \mathrm{mln}$ PLN (,Rzeczpospolita” 2018, s. 21). Należy zatem z nadzieją patrzeć na propozycje Polskiego Towarzystwa Crowdfundingu zmierzające do likwidacji prawnych barier jego rozwoju.

Kolejnym etapem w rozwoju finansowania społecznościowego jest blockchain crowdfuning, czyli pozyskiwanie funduszy z wykorzystaniem technologii blockchain, $\mathrm{tj}$. rozproszonej bazy danych $\mathrm{w}$ internecie, przez start-upy, produkcji własnej kryptowaluty i jej sprzedaży potencjalnym sponsorom ogłoszonego projektu. Jej wartość uzależniona jest od sukcesu projektu. Blockchain crowdfunding uważany jest za najbardziej czystą formę finansowania społecznościowego, ponieważ pozwala na eliminację pośrednika pomiędzy inwestorem a firmą. Do pozyskiwania funduszy nie jest potrzebna żadna platforma, co oznacza istotną oszczędność kosztów (https://translate.googleusercontent.com/translate, data dostępu: 27.03.2018).

\section{Podsumowanie}

Podobnie jak w wypadku innych, innowacyjnych sposobów finansowania, takich jak np. sekurytyzacja, mezzanine, venture capital, anioły biznesu, również jeśli chodzi o crowdfunding można w dość odległej przeszłości znaleźć jego pierwowzory. Jednakże ze względu na rewolucyjną zmianę w sposobie jego realizacji i mechanizmie funkcjonowania, wzroście jego kompleksowości, zakresu i form zastosowania, jest on uznawany za jeden z najnowszych instrumentów stosowanych w celu pozyskiwania kapitału w systemie collaborative finance, czyli bez udziału tradycyjnych pośredników. Dla crowdfundingu rozstrzygającymi czynnikami było z jednej strony pojawienie się największego wynalazku w technikach informacyjno-komunikacyjnych, jakim jest internet, z drugiej zaś wystąpienie zapotrzebowania na alternatywne źródła finansowania w sytuacji, gdy wskutek globalnego kryzysu finansowego nastąpiło zaostrzenie warunków udzielania kredytu bankowego (regulacje Basel III). Występującą lukę w finansowaniu małych i średnich projektów oraz młodych przedsiębiorstw w coraz większym zakresie niwelują innowacyjne metody finansowania, bardziej dostępne i efektywniejsze w porównaniu z tradycyjnymi. W ich zestawie crowdfunding odgrywa względnie niewielką, aczkolwiek coraz ważniejszą rolę i może być traktowany bardziej jako komplementarny aniżeli substytucyjny sposób finansowania i tylko w zasadzie w odniesieniu do niewielkiej skali projektów. W odróżnieniu od innych innowacyjnych metod pozyskiwania środków finansowych jego kanałem jest 
wyłącznie internet, a celem - finansowanie zarówno działalności charytatywnej, jak i komercyjnej. W związku z tym fundatorzy dzielą się na uczestniczących z pobudek ideowych oraz - tak jak w pozostałych sposobach finansowania $\mathrm{z}$ chęci zysku.

Wydaje się, że można prognozować dalszy rozwój crowdfundingu, przede wszystkim ze względu na jego niepowtarzalny, hybrydowy charakter. Żaden inny instrument finansowy nie jest stosowany do realizacji celów zarówno filantropijnych, jak i przynoszących korzyści materialne. Z tych względów wypełnia on pewną lukę, nadając systemowi finansowania bardziej holistyczny charakter. Szybko zmieniająca się rzeczywistość społeczno-gospodarcza z pewnością będzie oddziaływała na jakościową i ilościową ewolucję crowdfundingu, której różne aspekty powinny być przedmiotem stałej obserwacji i naukowego wyjaśnienia.

\section{Literatura}

Beck R. (2014), Crowdinvesting, Börsenmedien AG, Kulmbach.

Crowdfunding for SMEs (2016), red. R. Bottiglia, F. Pichler, Palgrave Macmillan, London. Crowdfunding in Europe. State of the Art in Theory and Practice (2016), red. D. Brütje, O. Gajda, Springer.

Dziuba D.T. (2015), Przesłanki badań w zakresie ekonomiki crowdfundingu, „Roczniki Analiz Ekonomicznych SGH”, nr 36.

Hamari J., Sjöklint M., Ukkonen A. (2016), The Sharing Economy: Why People Participate in Collaborative Consumption, ,Journal of the Association for Information Science and Technology", vol. 67, nr 9, https://doi.org/10.1002/asi.23552.

Kalabota M. (2014), Crowdinvesting, GRiN Verlag, München.

Kalinowski Ł. (2015), „Crowdfunding” - nowy element tworzqcej się gospodarki spotecznościowej. Wyzwania prawne, „Rynek - Społeczeństwo - Kultura”, $\operatorname{nr} 3(15)$.

Koch R. (2012), Crowdinvesting und Peer-to-Peer Lending, Ikosom, Berlin.

Mitręga-Niestrój K. (2013), Crowdfunding - Worldwide and Polish Exeperiences, „Annales Univeritatis Marie Curie-Skłodowska", vol. XLVII, nr 4.

New Approaches to SME and Enetrpreneurship Financing. Broadening the Range of Instruments (2015), OECD, Paris.

Niam Y., Shamika R. (2017), The Current and Future State of the Sharing Economy, Brookings India Impact Series No. 032017.

Onnée S., Renault S. (2016), Crowdfunding, Principles, Trends and Issues (w:) Research Handbook on Digital Transformations, red. X. Ollejos, M. Zhegu, Edward Elgar, Cheltenham.

Post D. (2017), Crowdinvesting als Finanzierungsmethode. Chances und Risiken aus Sicht eines Investors, GRiN Verlag, München.

„Rzeczpospolita” (2018), $\mathrm{nr} 4$.

Schwethelm Ch. (2014), Crowdinvesting als Finanzierungsalternative für mittelständischer Unternehmen und kritische Analyse aus Unternehmenssicht, Verwaltungs - und Wirtschaftsakademie und Berufsakademie, Göttingen. 
Schwienbacher A., Larraldde B. (2010), Crowdfunding of Small Enterpreneurial Ventures

(w:) Handbook of Enterpreneurial Finance, Oxford University Press, Oxford.

Wilson K.E., Testoni M. (2014), Improving the Role of Equity Crowdfunding in Europe's Capital Markets, „Bruegel Policy Contribution”, nr 9.

\section{Crowdfunding as an Innovative Method of Financing Small and Medium- -sized Enterprises}

(Abstract)

An innovative form of financing, crowdfunding consists of raising cash online to realise charity and commercial projects. It has played a smaller role than other forms of innovative financing that do not rely on traditional intermediaries. With a relatively short history, advantages and constraints that are not well known and, in many countries, a lack of right legal regulations, confidence in its effectiveness is rare. This holds particularly in the countries of East Central Europe, including Poland, which have only gradually adopted the global economy's instruments and innovative methods of financing. There is therefore a need to disseminate knowledge on crowdfunding and to show that it can meaningfully increase development, especially of small firms and start-ups, as a complementary and sometimes alternative source of financing. The paper uses empirical, theoretical and general logic methods to analyse the subject literature, reports from international organisations and online sources of information.

Keywords: crowdfunding, Internet, start-up, financial innovation. 